\title{
Spirituality and beliefs of Colombian internal conflict survivors
}

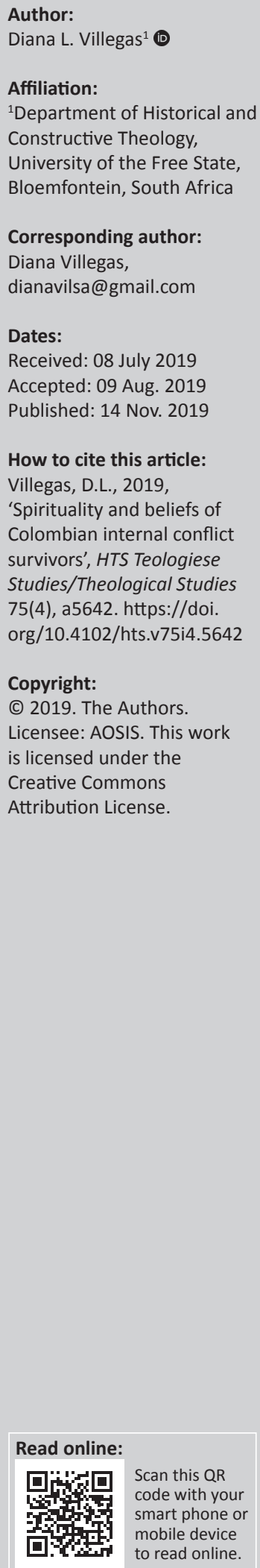

Remarkable stories of resilience and forgiveness have been reported in the wake of the internationally recognised peace process in Colombia. From the perspective of Christian spirituality, this study seeks to understand the individual and communal values, beliefs and practices that made the reconciliation and restoration of a community possible after severe dislocation and violence, some of it of neighbour against neighbour. Interviews conducted in the field (in San Carlos, Antioquia, Colombia) and transcribed by the author were used as texts. Transcripts were studied taking into account cultural, geographic and historical contexts. I found that a deeply rooted family- and community-based Catholic culture, brought by the Spanish in the 16th century and continuing to influence this rural area, offered values, beliefs and devotional practices that gave meaning, strength and empowered the ability to forgive. Also, psychological and pastoral tools for grieving, together with sociological and political values about reconciliation and the rebuilding of a community's fabric, intertwined with the religious values to deepen the capacity for reconciliation and community rebuilding. The experiences of these interviewees reveal a form of Christian spirituality lived through family and community ties that was augmented and empowered by values and practices of non-religious institutions, making possible significant personal and communal journeys of transformation and the concomitant remarkable resilience.

Keywords: spirituality; spirituality of war survivors; popular religion; popular devotions; victims of colombian civil war; Hispanic spirituality.

\section{Introduction}

What beliefs and practices of Colombian internal conflict survivors have made it possible to live through violence and loss in a constructive manner, enabling many to reconstruct shattered lives, to return to their rural communities and to rebuild these communities? What has enabled towns to accept programmes of reconciliation with their perpetrators? ${ }^{1}$ While this lived reality of resilience and reconciliation has been examined from perspectives such as ethnography, history and others, I have found no studies regarding the spirituality of the conflict survivors.

Through interviews conducted on location, in this article written from the perspective of the discipline of Christian spirituality, I document and analyse the experience of the survivors of the violence in San Carlos, Antioquia. ${ }^{2}$ These interviews, conducted in October 2018, show how a spirituality rooted in family traditions and religious beliefs becomes intertwined with other values and practices from non-religious sources to strengthen individual spirituality; it shows how this spirituality gave rise to processes of both individual and communal transformation in response to an experience of displacement, cruelty, loss and chronic fear.

\section{Methodology}

The contribution of this article to scholarship in the field of Christian spirituality lies primarily in collecting and making available the historically significant spirituality of a set of persons whose 1.Stories of remarkable resilience and forgiveness have been described in the Colombian media and documented by the Centro Nacional
de Memoria Histórica (CNMH) (National Centre for Historic Remembrance), an institute of the Colombian government founded to
uncover the truth about the injustices and violence perpetrated, to bring about reconciliation and to attend to the victims of the acts
of terrorism by the armed groups. See the Centre's website, www.centrodememoriahistorica.gov.co (available in English, French and German as well as Spanish).

2.In rural Colombia, the name of a village also extends to its veredas, which are rural subdivisions of the area surrounding the village. Those interviewed lived both in the town itself and in the surrounding veredas. Antioquia is a province in North Western Colombia.

Note: HTS 75th Anniversary Maake Masango Dedication. 
beliefs and practices have not been recorded and are unlikely to be documented from the perspective of spirituality. The methodological challenge involved both finding survivors of the Colombian internal conflict that I could interview and determining the best approach for recording their experience. A scholar at Centro Nacional de Memoria Histórica $(\mathrm{CNMH})^{3}$ provided initial contacts with persons who had already collaborated with $\mathrm{CNMH}^{\prime}$ s inquiries; ${ }^{4}$ these persons recommended others.

Through this process, I selected a small sample of persons of different ages and levels of education who were available during the 3 days I spent in San Carlos. Interviewees were first approached by those who recommended them and were told I was a theologian doing a study about the spirituality and values of Sancarlitanos. ${ }^{5}$ All those interviewed had told their stories of survival in healing groups, to government workers or to $\mathrm{CNMH}$ researchers, and a couple to the Colombian press; all had accepted that outside persons were interested in understanding their experience, which they were eager to share.

I wanted to record the experience of the Sancarlitanos so that when transcribed the interviews would provide texts equivalent to a spiritual journal or part of a spirituality memoir; in other words, I sought personal reflection of persons' experience of God; I sought first-person accounts about values, beliefs and practices, and how these made possible living through absurd tragedy with meaning, and with constructive and forgiving acts. To obtain such narratives from a small sample of persons (a bigger sample was not logistically possible), the technique of data collection used was that of an interview akin to those one practices in spiritual direction, ${ }^{6}$ where the person is invited to share their experiene and reflection on that experience in an open-ended manner. The recording of these narratives provides the warrant of their originality. ${ }^{7}$

The interview transcripts are, thus, akin to a spiritual journal, but they can also be seen as texts to be studied by others from the perspective of narrative theory, ${ }^{8}$ which asserts that narratives (stories) can 'be considered as texts in that they consist of an "author's" meaningful communication to an "audience"" (Ganzevoort 2012:216). In this case, the interviewees are the authors of a narrative addressed to me, the immediate audience; the transcripts of their narratives become texts for a wider audience. Narrative theory further maintains that humans create meaning through stories; we innately try to sort out 'what the events in our life and world mean to us and ... [create] at least a meaningful story from the elements that present 3.The scholar, Lina Maria Díaz, was one of the investigators contributing to CNMH (2010). 4.These were of a sociological, ethnographic and political science nature (see CNMH 2010). 5.As the citizens of San Carlos refer to themselves.

6.Besides being a scholar of Christian spirituality, I am a trained spiritual director with many years of experience.

7.With the permission of the interviewees, I recorded and personally transcribed the recordings. Interviewees were told that their names would be changed for confidentiality; all understood parts of their stories would be published.

8.For a historical study of the experience of the Sancarlitanos, including narrative theory from a historical perspective, see Restrepo (2011:159-162). themselves to us' (Ganzevoort 2013:15). The stories shared by the Sancarlitanos were precisely expressions of how they created meaning as they wove their internalised view of who God is for them, their values and beliefs and the memories of what they had lived through (see also Ganzevoort 2012:219).

\section{Cultural and historical context}

\section{Iberian Catholicism}

Interpretation of the findings, the more traditional method in Christian spirituality scholarship, focuses on historical and cultural contextualisation of the narratives recorded and transcribed, in order to better understand and analyse the experience of the Sancarlitanos. I start with the significance of geography. San Carlos lies in a part of the Andes that has deep valleys one after another amidst which towns and farmland are perched. Travel up, down and around these valleys has been difficult and has resulted in populations who have remained in the same location for many generations. ${ }^{9}$ Geography made possible the gathering of illegal armed actors out of easy reach of government troops. In great part because of this geography, these populations have retained a strong influence from the Spanish who arrived in the 16th to 18th centuries, ${ }^{10}$ including a particular inculturation of Catholic beliefs and practices. Sancarlitanos are formed by a version of pre-Trent Iberian Catholicism that was brought by the Spanish to Latin America in the 16th century. ${ }^{11}$ Iberian Catholicism emphasises the visual and the symbolic, as well as communal rituals, an inheritance of medieval piety. Faith and beliefs are transmitted and expressed through devotions that are vehicles for meaning and strength, and mark significant community events and daily life (see especially Espín 1997:69-71, 117-121, 24-27). Sancarlitanos are heavily influenced by the practice of devotions which have been central in sustaining them through the horrors of the civil war. ${ }^{12}$ Furthermore, Iberian Catholicism is the family- and community centred; thus, the beliefs of the interviewees were acquired in the family and many values of Catholicism were also the assumed values of most in the community. These traditions rooted in Iberian Catholicism made possible a significant part of the strength, resilience and ability to forgive described below.

\section{Civil war}

Colombia's violent war between the guerrillas and the paramilitaries $^{13}$ is a major historical reality marking the

9.I reached San Carlos by public bus after a 4 -h trip from Medellin (the second largest city in Colombia, capital of Antioquia), which as the crow flies would be less than $80 \mathrm{~km}$ away. One would need a four-wheel drive vehicle to travel this same road privately.

10.The countryside was settled by the Spanish in the 16th century, the town of San Carlos itself was founded in 1776 (Restrepo 2011:162)

11.For an excellent study of Iberian Catholicism in Latin America and among USA Latinos, see Espín (1997).

12.The Catholic Bishops of Latin America meeting in Aparecida, Brazil, in 2007, described the significance of the popular religiosity for the people of Latin America and recommended its encouragement for evangelisation of the continent (see CELAM 2007:7, 37, 43, 93, 99, 127, 261-264, 300, 549).

13.The CNMH has published a 432-page document with a history of the armed conflict (CNMH 2013), a complex history of internal strife that had roots in the disputes between the traditional conservative and liberal parties, which were den settled throug countryside. In the early $1960 \mathrm{~s}$, movements developed in rural areas to fight fo the rights of peasants, who felt left out of the political process and the fights between the traditional parties; these became the guerrilla movements, two of 
spirituality of Sancarlitanos, as their stories reflect the way persons dealt with dislocation, loss, cruelty and extreme fear. $^{14}$ San Carlos' mountains are rich in potential hydroelectric power, so that major hydroelectric power plants were built there. Some Sancarlitanos, however, felt they were exploited by the government and big business, while they reaped few benefits and were charged too much for power coming from resources of their ancestral land. ${ }^{15}$ The guerrilla-paramilitary violence started when the guerrillas saw an opportunity to expand their territory with the excuse of seeking justice for the population. ${ }^{16}$ Some locals supported the guerrillas, whose presence resulted in the first wave of violence and disappearances. As the paramilitary emerged on the Colombian scene, they arrived in the east of Antioquia to 'cleanse' the area of guerrilla. San Carlos and the surrounding countryside were terrorised in the fight between the armed groups (see Restrepo 2011).

In 2005, the Ley de Justicia y Paz (Justice and Peace Legislation) was passed by the Colombian Congress to make possible the surrender of the paramilitary groups and their reintegration into society. With this surrender, peace began to come to San Carlos; for at the same time that the paramilitary surrendered, the guerrilla's domination of territory had been significantly reduced by government offensives. ${ }^{17}$ In this context, reconciliation between demobilised paramilitaries and fellow townspeople (many were victims of the latter) was promoted by the government as part of the effort to bring peace to the Colombian countryside. This political interest in reconciliation intertwined with efforts towards the same goal by the church and by groups with both religious and non-religious roots. Thus, healing of resentment, hatred and the desire for revenge were prompted by a variety of entities reaching out to the Sancarlitanos. The spirituality of forgiveness reported below was forged, then, in the context of these calls for reconciliation by the government as well as by local citizens who had to reach out to the demobilised paramilitaries to find out where loved ones who disappeared were buried.

\begin{abstract}
(footnote 13 continues)
which have survived into recent times, the FARC or Revolutionary Armed Forces of Colombia, the largest guerrilla, which ended up holding large parts of Colombian territory as much as $40 \%$ in 2000 by some estimates (CIDOB). It is this guerrilla, which signed a peace agreement in 2016. The second largest guerrilla ELN, National Liberation Army, is still active though confined to limited areas of the country. Paramilitary groups started in the 1980 s to protect large landowners from the guerrillas, as the government was unable to do so. Thes paramilitaries became a major force, which sowed brutality in various parts of the Colombian countryside, sometimes joined by government armo forces, 'rid' the councis 'rid" the countryide comes allied . was caught in these power struggles. The paramilitary organisations handed in their weapons between 2003 and 2006. As of April 2019, the ELN, drug cartels, as well as descendants of both paramilitaries and FARC involved in drug trafficking continue to be the cause of serious violence in some parts of the country. For brief, balanced English online summaries about the history of the armed conflict in Colombia, see CIDOB and Felter and Renwick (2017). Note: Online summaries can be quite biased depending on the political perspective
\end{abstract} from which they are written.

14.For historical, ethnographic and sociological discussions of war in San Carlos, see CNMH (2010). See also Osorio Campuzano (2013) and Restrepo (2011).

15.Testimonies of interviewees. See also Vélez Henao and Vélez Gómez (2015).

16.Other strategic advantages were a geography where they could hide from the Other strategic advantages were a geography where they could hide from the plants, which could be taken 'hostage' in their fight with the government.

17.For a more detailed description of the guerrilla wars in San Carlos, see Restrepo (2011).

\section{Testimonies}

\section{God as protector, answer to fear}

Studies conducted by the $\mathrm{CNMH}$ have documented the resilience of the Sancarlitanos. Many displaced by threats, killings and loss of loved ones have returned; the countryside is being productively used again, and neighbours have forgiven each other (see CNMH 2010). Thus, the first question I posed was, what beliefs and practices made this remarkable resilience possible? Following are testimonies in response to my question, which give witness to strong values about family unity and mutual support. This family-centred way of living was intertwined with daily prayer to God, believed to be strongly present in everyday life with power to protect and guide. Thus, all interviewees engaged in pleas to God for protection and help, pleas made mostly through traditional Catholic devotions, practised both individually and as a family, following in the tradition of Iberian Catholicism.

\section{Darlene}

Darlene $^{18}$ and her family returned to San Carlos when the mayor offered housing and other benefits to families who returned. Soon after their arrival in town, the person assigned by the town to escort them was shot dead in front of their eyes. This devastating experience consumed her with fear and made her and her husband doubt the wisdom of returning to the vereda where her husband had a farm that had been in the family for generations. He had to leave his farm and met Darlene in Medellín. ${ }^{19}$ She had grown up in a family where the mother was devout, so she learnt about God and prayer at home. Her most significant belief is in God's love; and this God of love is present in everything. Darlene explained that she had not prayed regularly until fear made the need for God urgent, so that the belief that God would help her family in their need became a dominant dimension of her life and that of her husband. For months, she went between the homes of relatives and church, trying to decide if they should leave town again or go ahead with their plan of returning to the vereda to farm:

'My life consisted of going from home to church ... it was my routine ... I went to church every day. I couldn't find anything else to do but go to church. I didn't go sit in a coffee shop, I didn't go out to eat an ice cream, I spoke to no one ... [My husband and I] went to church, we prayed... The love we had for each other and God's love were the only things that offered us support [in the first months in town] ... [in church] we felt something like a peace, one felt held ... one felt protected and as though someone walked with us ... when one is afraid one prays more.' (Darlene, Interview 05 October 2018, Vereda Arenosa, San Carlos) ${ }^{20}$

\section{Paul and Cathy}

Paul and Cathy stayed as long as they could hold out in their farm located in a mountainside contested between the paramilitaries and the guerrillas. At night they could hear

18.Names are changed in the interest of protecting identities.

19.A large percentage of displaced persons from San Carlos moved to Medellín.

20.All citations are from transcriptions I personally made of interviews I conducted. Translations are mine. Recordings are in my possession as warrants for the texts. 
gunfire and explosions, and so they lived in constant fear that their home would be hit. The couple, their children and sometimes relatives from nearby farms would gather in prayer, usually to say the rosary; sometimes spending the whole night saying the rosary together. They trusted that the Blessed Mother would intercede for them. They had implicit confidence that God would listen to their plea for protection. In addition, gathering together to pray afforded comfort in the midst of terror and made the family feel united in dealing with fear. Paul and Cathy further expressed the importance of thanking God for the blessings of each day. They as others I interviewed believed that the prayer of thanksgiving was most important in keeping, as it were, the right channels of communication open with God whose protection and help were essential:

'We suffered a great deal of fear because we had to manage both groups, the paramilitaries from below and the guerrilla from above. And so we were in the middle. I would say it was faith in God that saved us. God was always with us. We always came together to pray, to pray and thank God for each day that dawned and after so much violence, so many shots that we heard. Thanks to God we woke up OK, fearful, but we woke up alive ... Of course no matter how much faith, we are sinners, and so we felt fear ... We have always been glued to God, here or elsewhere, so God also helps and blesses.' (Paul and Cathy, Interview 05 October 2018, Vereda Arenosa, San Carlos)

\section{Brenda}

Brenda, a schoolteacher, remained in San Carlos during the war, even though her brother was among the disappeared ${ }^{21}$ and her own life was threatened more than once for continuing to teach against the orders of the paramilitaries. The latter believed small vereda primary schools ${ }^{22}$ taught the guerrilla's children, so preventing schooling in these venues was one of their war strategies. Brenda's strong values about commitment to the well-being of her community intertwined with her faith in God's power led her to go to work each day:

'I felt I couldn't abandon my community, because the role played by the teacher was extremely important. Wherever the teacher was, there was community. If the teacher left, then the people left. Hope was lost. Whenever the teacher got to the schools, it was because she or he trusted in God, because one left the town without any protection. No army, no police, nothing, only God's mercy. One rode a horse or walked, normally walked, that's it. On the road one might see dead bodies, or members of the armed groups ... So one was never short of fear, but God's strength made one get up and go again.' (Brenda, Interview 06 October 2018, San Carlos)

She explained that she would carry a small transistor radio on which she listened to the Mass on the way out to the schoolhouse and recited the rosary or the 33 creeds $^{23}$ on her way back. In addition to listening to the Mass and recitation of prayers, she carried images of the Blessed Mother, another

21.Brenda described the story of the disappearance and recuperation of her brother's body to a Colombian journalist who published the account in Tamayo Gómez (2017)

22.Given the transportation problems of the mountainous terrain, many veredas had basic structures where teachers arrived on foot or horseback to provide schooling for the first few grades.

23.One of many devotions learnt in the family, involving repetition of the Creed. devotional practice of intercession for help and a form of comfort when in need. More than once she feared for her life, but nothing ever happened to her. She believes this was because of God's protection entreated through her prayers:

'I never felt alone. He (God) was always with me. I remember I always wore a medal of Mary, which I would hold, on the path uphill, and with her I returned, and it was always this way. She was my shield.' (Brenda, Interview 06 October 2018, San Carlos)

Besides each day's dangers, she experienced a dramatic lifethreatening event where she was not harmed, she is convinced, because of the prayers of many evidencing her strong belief in intercessory prayer. The paramilitary leader ordered several of the teachers to appear before him (not doing so meant certain death). Before going with the others, Brenda went to church to pray before the Blessed Sacrament. ${ }^{24}$ Soon the other teachers arrived to do the same. On the way out of the church, they asked for the prayers and blessing of the priest. When faced with the paramilitary commandant, she held tightly to a paper image of the Blessed Mother, praying hard that God give her courage and guide her in order to speak up to him. She is convinced God responded, giving her wisdom and as the gospel says, gave her the words to say (Mt 10:19-20). She felt the strength to ask the commandant why he wanted to kill the teachers. 'Because they taught the children of the guerrilla', he explained. Brenda felt God gave her the words and strength to reply:

'Don't say that to me. I teach the children that come; there is no parent who comes and says to me, 'teach my child because I am a guerrilla member'. If a parent is a guerrilla, you would know, since you know who they are. I don't know any members of the guerrilla.' (Brenda , Interview 06 October 2018, San Carlos)

She had the courage to keep arguing with the man until he gave her the list of those due to be killed. She kept praying, though full of fear, and felt inspired to shred the list and eat it while in the man's presence, so the list would disappear, and no other commandant would get it. When safely home, she could hardly recognise her own actions. 'I didn't do all this. God did all this'. She felt that all the prayers, from those in the church before the Blessed Sacrament, to the prayers of the priest, to the prayers for the Blessed Mother's help and intercession had given her the strength, the courage and the words to speak to the commandant. And God, because of the prayers, had worked in the heart of the commandant. She eventually suffered post-traumatic stress disorder (PTSD) and benefited from professional help; this confirmed for her that at the moment of her confrontation with the commandant, it was God's wisdom and strength working through her.

\section{Annie}

Annie was a community leader, someone with instinctive leadership skills and a self-acquired wisdom.

Of all the interviewees, she is the least educated and the oldest (58 years old). While brought up Catholic, she is a

24.Praying where the consecrated hosts are kept in a side chapel of the church or put up on the altar for veneration is a popular devotion that is not only part of Iberian Catholicism but a church-wide devotion of the Catholic tradition. 
seeker who questioned aspects of her tradition and sought wisdom in books checked out of the town's public library. ${ }^{25}$ God was a personal other who protected, guided and responded to pleas, so she resorted to prayer to cope with fear, to seek protection and to deal with threats. She prayed with the Bible rather than turning to the devotions of her culture and prayed by contemplating God in nature and in events of daily life that were filled with love and justice. She was less involved than the others in church attendance.

She had lost her husband and 9 months later, one of her sons, who was 17. Sometime after her husband's death, the paramilitaries showed up amidst the few homes that constituted her vereda. She heard someone point out her home to the leader of the armed group; as a community leader she was considered an enemy. ${ }^{26}$ She hid her younger son who was still at home and got out her Bible and read the psalms to ask for protection and for courage. She felt God led her to specific psalms, which she recited as the shots rang out, shots which eventually ended the lives of 11 members of her vereda. However, she was spared, she is sure, because of God's protection:

'The only thing that sustained us was God. We are blessed by God's mercy. God always gathered us in. And so the only thing I did was grab onto the Bible ... In those moments it's like a cassette playing quickly, one makes a sort of examination of conscience, what's the worse thing ... I have done. So I made that examination and I started to read the Bible ... I read psalms, psalms - when I heard rapid fire, tatatata, I went into neutral. When the sound stopped, I could go on reading ... I think God inspired me as to which psalm to read because I opened and read what I found and I had time to read the whole psalm before another bout of rapid fire began. And so I grabbed on strongly to the Bible. And I think the Word of God placed a sort of curtain here that sort of made this house invisible because they didn't come in.' (Annie, Interview 07 October 2018, Vereda Dos Quebradas, San Carlos)

\section{Devotions and formation}

How did these Sancarlitanos acquire this faith? All reported they learnt their faith at home. The practice of parents and grandparents who trusted in God, invoked God daily, found strength in God and engaged in various devotions was passed on by example. I directly inquired of all whether instruction at school or in church had something to do with their beliefs and practices. All said that Masses, devotions and other activities at church supported what they learnt at home, but they were not the main source of their practices and beliefs. None reported anything equivalent to Sunday school classes. Some spoke of the priests going to the schools but said this did not have much influence on their devotional practices and faith. For instance, Paul and Cathy described how their parents prayed three times a day; in Paul's family, when any child was at home at times of prayer, his mother

25.Such an interest in learning and the pursuit of reading was quite unusual for someone in her context but a testimony to the quality of the local community leaders.

26.Community leaders were thought to collaborate with one faction or another of the armed actors. Although true in some cases, most were concerned with the well-
being of their families and their rural neighbours rather than pursuing any being of their famil
particular ideology. would ask the child to kneel and say, 'here, son this is how it's done' (Paul and Cathy, Interview 05 October 2018, Vereda Arenosa, San Carlos).

Brenda's family was equally prayerful, punctuating parts of the day or family events with thanksgiving or intercession. Brenda remembers:

'Every night we [the children] prayed with my father and mother. With our grandparents, of course, whenever we arrived there would be a prayer; for them there always had to be a Hail Mary at noon. When the bells [of the church] rang at noon they prayed the Angelus. Yes, all of this we learned at home.' (Brenda, Interview 06 October 2018, San Carlos)

Annie's mother was very devout and communal prayer meetings were held in her house. In the home, it was assumed God was central to life. In this milieu, Annie learnt to pray with the Bible and trust in God.

Joan told me, 'I remember mom and dad always, they always pray the rosary, and so they prayed and in that way, as they prayed they taught us (the children)' (Joan, Interview 06 October 2018, Vereda Arenosa, San Carlos). She and her husband pray every day and involve prayer in the key aspects of their lives as a result of this family example. For instance, at the business she runs with her husband, Joan gathers all employees to thank God and pray to start the day and similarly ends the business day with prayer. As she and her husband learnt prayer at home, they are passing this on to their daughter, who at 16 willingly prays of her own accord.

These and all interviewees learnt at home not only prayers to say and devotions to pursue, but most of all an unquestioned trust in God and an ethos about the importance of asking God for help. God was not primarily someone to worship on Sundays in church or a judge of behaviour (though the latter could also be the case), but God was a very real being that accompanied the daily life of the family and the town. All interviewees described processions and novenas that gave expression to family devotions. Through such devotions and other prayers, God was addressed as a matter of course. We have seen how these foundational beliefs rooted in the family were a significant source of strength when confronted with the devastation of war.

\section{Forgiveness}

As mentioned in the introduction, remarkable stories of forgiveness emerged following the cessation of Colombia's war with and among guerrilla and paramilitaries. These stories disclose journeys of self-transcendence that were mediated not just through individual efforts but also in striking ways through communal initiatives. In San Carlos, strong faith in God rooted in the Iberian Catholic culture of many generations is a foundational factor that made forgiveness possible. This foundation was strengthened by the Catholic Church, which also explicitly made efforts through calls to prayer and by offering grieving and healing processes. In addition, forgiveness was enabled through 
communal efforts by local and national groups as well as government agencies that sought to rebuild the social fabric of a town that had lost $40 \%$ of its population. ${ }^{27}$

Mary: Mary was shot when an armed group attacked a bus of university students, her brother disappeared and his body was never found; she and her family were displaced. Despite her suffering, and even though she has come to know which persons were involved in the attack on her, she reports she never felt hate or an inner push towards revenge. Because the town of San Carlos itself (apart from its veredas) is small, she runs into her perpetrators periodically. While she is not friendly with them, she is not disturbed or triggered to anger or hate.

She ascribes her ability to accept and forgive to family values shared by many in the town and by the efforts towards grieving and forgiveness led by the church. In terms of family values, in her home, keeping resentments and seeking retaliation were discouraged:

'Because if since you are little, if you are the victim of an aggression and you have no principles or values and you make that aggression into something personal, something big, something generating hate and resentment, then something small can make you furious. But in my family we have principles, we have been a very peaceful, traditional, very Catholic family, and so the values that were taught in the family make it easier for us to grieve [without hate]. We were never taught that one ought to hate the other because she took away a toy. That never happened. And so I feel that I personally have never lived with hatred. I've never hated anyone. I know that in this life I am no one that can judge another person.' (Mary, Interview 05 October 2018, San Carlos)

The ability to follow through on what she was taught as a child is supported by the role of the church, which she and the others felt did not abandon them. 'The government abandoned us', she told me. By contrast, two of six priests remained during the war risking their own well-being, as they were also threatened by the warring factions. The priests preached that there must be forgiveness and no retaliation, or the cycle of violence would continue. They offered daily invitations to prayers for the conversion of the armed actors at times during the Mass, during other prayer events in the church and at times over loudspeakers many in the town could hear. There were also gatherings where people could process their grief, anger and other feelings. Mary explained that through these community-wide experiences, God offered her healing and strengthened the willingness to forgive learnt in her family.

Annie: Annie who lost her husband and one of her sons and was displaced from her farm for 5 years describes her spontaneous feelings towards her perpetrators:

'In my whole being there was so much pain (at her losses) that I couldn't think about revenge. I never thought about those sorts of words (vengeful words). I always felt a sort of sadness for

27.In 1985, San Carlos had a population of 29156 . Given the displacement caused by the violence, the population was reduced to 11854 in 2005, when the paramilitaries demobilised and peace began (Restrepo 2011:169). those persons, they knew not what they were doing ... Yes, I felt sorrow for the people who did that, I don't know why. I don't understand myself. I never did feel rage.' (Annie, Interview 07 October 2018, Vereda Dos Quebradas, San Carlos)

She finds in herself no feelings of anger or hatred, but rather feels a sadness and sorrow for the perpetrators. There is some sort of compassion for them, knowing that many are also young men from the town who became caught up with the paramilitaries for reasons other than ideology. ${ }^{28}$ This experience, some of which she does not understand, fits with long-held values, rooted in her family and Catholic culture, which are embodied in a story she told me about guiding her youngest son.

At the beginning of the violence in the vereda, before his father died, one of her son's friends asked him if he would take revenge on someone who killed his brother or father. The son (at the time 9 years old) asked Annie about this and she responded:

'If one seeks revenge, that starts a never-ending chain. And you see, there would be a very great pain. It's a supposition, but if something happened to any of us in the family and if you should take revenge to harm the other, keep in mind that what we would feel would be felt by the family of the other person. And the family would suffer though they are innocent, because those who get punished are those left behind not those who die. The one who dies, is dead, and the one who suffers is the one left behind; so that's a chain of vengeance, suffering and pain. And so stop. Vengeance is bad, vengeful thoughts are bad. That's the advice I gave my son.' (Annie, Interview 07 October 2018, Vereda Dos Quebradas, San Carlos) ${ }^{29}$

Brenda: Brenda, the teacher who lost a brother and whose life was threatened, spoke about her practice of surrendering everything to God and how this practice made forgiveness possible. As she surrenders everything else, she surrendered her hatreds so that God might transform these impulses; God's power would remove from within her hatred and any desire for revenge. The practice that most mediated this prayer of surrender was devotion to the Blessed Sacrament, that is, prayer in church where the communion hosts are reserved:

'When you hate, when you see the person ... you turn away and breathe, or you avoid the person in order to not see him, then hatred will continue [inside you] forever. But when you go and kneel before the Blessed Sacrament and pray for those persons so that God will change their sick mind, their bad decisions against the life of other human beings, then one is able ... You just pray for them and God takes care of the rest, so that when you go out and run into them you can say hello ... God retained my hatreds.' (Brenda, Interview 06 October 2018, San Carlos)

28.Young men who had no income to support themselves and their families were offered payments for joining up. Others were threatened with harm to their families if they did not join; others were kidnapped and forced to take part in violence at the risk of torture, their life or that of family members. Pastora Mira's violence at the risk of torture, their life or that of family members. Pastora Mira's in violent acts. The story is described in Tamayo Gómez (2017:57-79).

29. A few years later, the son wrote an essay about forgiveness for a contest as part of the community's efforts at reconciliation; he won the price telling the foregoing story. Through this essay, Annie's values were a witness and encouragement to reconciliation to other Sancarlitanos. 
Her personal devotion was strengthened through the church's role in promoting reconciliation. As we have seen, this took place through prayer for the perpetrators, through worship focussed on reconciliation and through other offerings that allowed people to share feelings and grieve.

For the Sancarlitanos had to find a way of accepting in their midst the paramilitaries who returned to town after having perpetrated atrocities on their neighbours. Such acceptance required that large numbers embark on journeys of healing and forgiveness. Brenda is convinced that the church's call to prayer for these men made possible the successful reintegration of many into the community:

'When the war began to wind down, then the church, the role the Church played was, let's pray for the perpetrators, let's pray that they change their ways, that God may change their mind that is so perverted; and so they gathered us in the Church to pray for them. They [the priests] invited us and most of us came. So, forgiveness didn't start when they said, the men [the paramilitary] are going to be reintegrated. Forgiveness began in San Carlos much earlier, because what the priest did was invite us to pray for those assassins. 'Let's pray for them so they change their thinking, that God change all the ways they think about hurting the population;' and so we began to pray, and the reintegration began to happen through God's grace. So when the men returned and the paramilitaries returned to town, the people accepted them.' (Brenda, Interview 06 October 2018, San Carlos)

Paul and Cathy: Paul and Cathy also assert that they have forgiven the former armed actors in their midst. They explain that the men who were very young at the time of the war are now their neighbours in town. They bump into them and treat them as they would any other neighbour. They wait on them without any problem when they come to their business. ${ }^{30}$ As in Mary's case, they ascribe their willingness to let go of resentment and feelings of retribution to family values that have been taught in their families for generations, and these values are related to their faith in a forgiving and merciful God. (Paul and Cathy, Interview 05 October 2018, Vereda Arenosa, San Carlos)

\section{Civil society and forgiveness}

In San Carlos, the spirituality that made possible letting go of fear, resentment, desire for retaliation and distrust was strengthened and empowered not just by the church but also by local groups formed to help one another deal with the effects of the war, and by government groups who sought to promote reconciliation. Institutions offered expertise in grieving processes and community building that taught the Sancarlitanos new skills. These, in turn, intertwined with their values and beliefs to make the individual and communal journeys of forgiveness and reconciliation possible.

Centro de Acercamiento para la Reconciliación y la Reparación (CARE) [Encounter Centre for Reconciliation and Reparation]

30.They have ponds where people fish Tilapia, which is then cooked and served in a beautiful mountain setting. offered processes for healing that benefited several of my interviewees. This centre was started by San Carlos women who sought out demobilised paramilitaries in the hope of learning where their missing children had been buried. This experience of joining forces to seek out burial sites inspired some to start CARE to formally organise for the recovery of victims' bodies, the healing of victims and their families and the repair of the social fabric of the town (see CNMH 2010:328334, 52-54). The leader of the group, ${ }^{31}$ Pastora Mira, eventually consulted with $\mathrm{CNMH}$ and the local Catholic Church. Through this institutional support, CARE convened meetings where persons were taught that to heal they had to let go of hatred and the desire for revenge; they were taught that they would find strength in forgiving their neighbours and in allowing trust among neighbours to be rebuilt. To be free of fear and PTSD, they needed to express their anger, desire for revenge and grief; processes were developed for such grieving. Participants in CARE workshops learnt to be heard and to feel comforted by their neighbours who had similarly suffered. The witness of many who were helped to find their loved ones encouraged trust in CARE's offerings, which then led others in town to join in the processes for grieving and forgiveness. That the founder herself forgave those who tortured and killed both a son and a daughter further added to such encouragement.

Brenda summarises the role of CARE in working towards forgiveness as a goal for the community as a whole:

'CARE brought about much that made it possible for San Carlos to rise again. One task was to gather women who were victims, who had lost a family member. [These women] were able to begin a grieving process, to talk about their lives, to tell their stories, the absences, their losses. And through other projects led by women ... they began to understand that it would be forgiveness that would help us be reborn, that hatred would make us sick, that this town, if full of hate, would never rise again.' (Brenda, Interview 06 October 2018, San Carlos)

CARE further helped in repairing the social fabric and setting an example of forgiveness and reconciliation by offering to be one of the places where reinserted young paramilitaries who lacked schooling could finish high school. CARE offered a powerful symbol of transformation of hatred, grief and fear as they eventually bought the house used as the paramilitary centre. Thus, this place of hatred and violence, where torture and murder had taken place, was transformed into one devoted to reconciliation and healing. ${ }^{32}$

Darlene describes in detail how CARE's work helped her and many of her neighbours heal:

'One might live with resentment, or bitterness or feel distrust because one has a pain lodged in one's soul. When you can't express this you live with feelings of bitterness, annoyance,

31.Pastora's son and daughter were both tortured and disappeared. She was one of the victims who shared her witness of forgiveness with Pope Francis at a public the victims who shared her witness of forgiveness with Pope Francis at a public gathering in Villavicencio, Meta, Colombia, on 08 September 2017. For a video of this witness and summary in English, see https://www.romereports.com/ n/2017/09/09/after-a-lifetime-of-suffering-this-woman-unites-her-pain-withGómez (2017).

32.From testimony by Brenda and other members of San Carlos. 
sadness, and so one says, 'Oh, look at that bad person!' But many times [we say this of our neighbour] because we don't know about our neighbours' sadness, their pain ... CARE taught us, and in this vereda we grew in such a way that values were rebuilt. And so we have been able to forgive. And so with CARE we met in groups and they led us through processes where one described one's problems, one witnessed to one's experience. And I learned from this ... Due to the work we did with CARE we began to consolidate the emergence of trust, values were recovered, trust, commitment, loyalty, getting to know our neighbours, know who each was.' (Darlene, Interview 06 October 2018, Vereda Arenosa, San Carlos)

Through the leadership of CARE and her involvement with the leaders of this group, Darlene herself became a leader helping in the reconciliation of San Carlos, through work promoting CARE and its values, through work bringing fish farming back to town and accepting demobilised armed actors into the cooperative that promoted the fish farming industry. She felt that through this work she was healing herself, helping the healing of hatred and resentment and rebuilding the social fabric of the community. These activities on behalf of reconciliation were intertwined with her basic religious beliefs and spirituality where God is love and God's love makes all possible:

'What brought us to San Carlos shows that love can accomplish all things. When there is love much can be accomplished. [Since I stayed in San Carlos] have been the best years of my life. I have been able to help others, to contribute to the development of the town, the quality of my life has improved, and so my basic word about God is that above all there is love. Family love, love for all that one does, because one should love all one does. [In San Carlos] I found a motivation for living, to move forward through helping others, and in me was born in a stronger way love for my neighbours, where one says to oneself, yes, I have problems and suffering but mine is small compared to that of others.' (Darlene, Interview 06 October 2018, Vereda Arenosa, San Carlos)

Darlene's story exemplifies a powerful journey of transformation mediated through family values and spirituality learnt at home that became more deeply rooted through suffering. Her journey was further empowered through both the spiritual support of the church and through new skills taught by community groups, some of these provided as part of a public policy to bring peace and reconciliation. ${ }^{33}$

\section{Conclusion}

In summary, the following values and beliefs contributed to the Sancarlitanos' remarkable resilience and ability to forgive: (1) widespread belief in the reality of God's presence in daily life as a being who loves and wishes to help, protect, comfort and guide. (2) The inheritance of Iberian Catholicism with its devotional practices that encourage intercessory prayer and mediate comfort and strength in the midst of fear and suffering. (3) Strong family ties intertwined with the family and community centredness of Iberian Catholicism. (4)

33.Other groups also offered teaching and processes for reconciliation, including the hydroelectric power plants, which brought in psychologists to help their employees (from Paul's testimony). See CNMH (2010:350-355) for discussion of efforts at reconciliation by other groups.
Community ties that include an ethos of acceptance of the other, exemplified in the acceptance of perpetrators who returned to the community and willingness to have compassion for the young men who were drawn into the armed groups. (5) These family and religious traditions formed persons who were unquestioningly open to the transcendent, so that the church and the community's call for forgiveness was accepted by many relatively easily.

Just as it can be said that religions emerged in human culture as people sought answers to ultimate questions about loss, suffering and evil, ${ }^{34}$ one can say that spirituality can arise in creative and strong ways through experiences of complete upheaval and severe suffering, the case of San Carlos. The community lived through atrocities that were certainly evil; they lived with absurd loss and the suffering all this caused; their countryside had been torn by violence and betrayal of neighbour against neighbour. This communal experience brought into play not only profound resources based mostly in a deeply rooted Catholic culture but also values about social reconciliation for peace.

The experience of San Carlos shows how a spirituality rooted in family-based values and religious beliefs can be strengthened by community efforts. Not only did the religious institution undergird values, but tools offered by non-religious actors deepened traditional spirituality. In the case of San Carlos, psychological and pastoral tools for grieving as well as sociological and political values about reconciliation and the rebuilding of a community's fabric intertwined with religious values.

If space had permitted, I would have further explored and discussed the links between individual and community spirituality and explored further how government policy can influence spirituality (in this case, the policy of reconciliation influenced by individual forgiveness). I would have discussed the experience of the Sancarlitanos in terms of existing studies regarding popular religion or popular devotion. The witness of the Sancarlitanos invites discussion regarding how popular devotions are interpreted vis-à-vis doctrinal teaching. ${ }^{35}$

\section{Acknowledgements}

I thank all citizens of San Carlos who made these interviews possible.

\section{Competing interests}

The author declares that there is no competing interest.

\section{Author(s) contributions}

D.L.V. is the sole author of this article.

34.See Villegas (2018:1-2).

35.A topic discussed at length in Espín (1997). See also Llywelyn (2017). 


\section{Ethical consideration}

This article followed all ethical standards for a research without direct contact with human or animal subjects.

\section{Funding information}

Partial funding for the publication of this article was provided by the University of the Free State.

\section{Data availability statement}

Data sharing is not applicable to this article.

\section{Disclaimer}

The views and opinions expressed in this article are those of the author and do not necessarily reflect the official policy or position of any affiliated agency of the author.

\section{References}

Barcenlona Centre for International Affairs (CIDOB), Conflicto en colombia Antecedentes históricos y actores, viewed 11 March 2019, from https://www. cidob.org/publicaciones/documentacion/dossiers/dossier_proceso de_paz en colombia/dossier_proceso_de_paz_en_colombia/conflicto_en_colombia antecedentes_historicos_y_actores (Website also available in English).
CELAM, Centro episcopal de lationamerica y del Caribe, 2007, Fifth general conference of the bishops of Latin America and the Caribbean, CELAM, Bogotá.

Centro Nacional de Memoria Histórica (CNMH), 2010, San Carlos: Memorias del éxodo en la guerra, Taurus, Bogotá.

Centro Nacional de Memoria Histórica (CNMH), 2013, iBasta Ya! Colombia: Memorias de guerra y dignidad, Imprenta Nacional, Bogotá.

Espín, O.O., 1997, The faith of the people: Theological reflections on popular Catholicism, Orbis, Maryknoll, NY.

Felter, C. \& Renwick, D., 2017, Colombia's civil conflict, Center for Foreign Relations, New York, viewed 04 April 2019, from https://www.cfr.org/backgrounder/ colombias-civil-conflict.

Ganzevoort, R.R., 2012, 'Narrative approaches', in B.J. Miller-Mclemore (ed.), The Wiley-Blackwell companion to practical theology, pp. 214-226, Blackwell, Malden, MA.

Ganzevoort, R.R., 2013, 'Religious stories we live by', in R.R. Ganzevoort, M. De Haardt \& M. Scherer-Rath (eds.), Religious stories we live by: Narrative approaches in theology and religious studies, pp. 1-17, Brill, Leiden.

Llywelyn, D., 2017, 'Devotion, theology and the sensus fidelium', New Blackfriars 98(1074), 171-187. https://doi.org/10.1111/nbfr.12268

Osorio Campuzano, R., 2013, 'Paramilitarismo y vida cotidiana en San Carlos (Antioquia): Etnografía desde una antropología de la violencia', Boletín del Instituto de Antropología (Medellín) 28(45), 130-153.

Restrepo, G.I., 2011, 'Memoria e historia de la violencia en san carlos y apartadó', Universitas Humanística 72, 157-188.

Tamayo Gómez, H.D.J., 2017, Dos velorios: San carlos, en el camino del perdón, Hilo de Plata, Medellín.

Vélez Henao, J.A. \& Vélez Gómez, L.D., 2015, 'Evaluación de las transferencias del sector eléctrico: El caso de San Carlos y el oriente antioqueño', Revista Ingenierías Universidad de Medellín 14(27), 147-161. https://doi.org/10.22395/rium.v14n27a9

Villegas, D.L., 2018, 'Spirituality and belief: Implications for study and practice of Christian spirituality', HTS Teologiese Studies/Theological Studies 74(3), 4933. https://doi.org/ 10.4102/hts.v74i3.5037 